\title{
IFRS adoption and firm value: African evidence
}

Henry Agyei-Boapeah ${ }^{1 *}$, Michael Machokoto ${ }^{2}$, Joseph Amankwa-Amoah ${ }^{3}$, Abongeh Tunyi $^{4}$, and Samuel Fosu ${ }^{5 *}$

\author{
Corresponding author: h.agyei-boapeah@soton.ac.uk
}

\begin{abstract}
We examine the impact of the adoption of International Financial Reporting Standards (IFRS) on firm value using a sample of African listed firms selected over the 2000-2015 period. Our results show that the adoption of IFRS positively impacts firm value. We further find that the impact of IFRS adoption on firm value is more pronounced in environments where there is a greater commitment to the rule of law. Moreover, the increase in firm value is more pronounced for firms with a higher degree of financial constraints. Finally, additional results suggest that the benefits of fully implementing IFRS are higher than those arising from partial/modified adoption. Our results are robust to controlling for other factors that affect firm value and to alternative sampling procedures.
\end{abstract}

Keywords: IFRS adoption; firm value; Africa; financial constraint; rule of law.

\section{JEL classification:}

\footnotetext{
${ }^{1}$ University of Southampton, Southampton Business School, Southampton, UK.

${ }^{2}$ The University of Northampton, Faculty of Business and Law, Northampton, UK.

${ }^{3}$ University of Kent, Kent Business School, Kent, UK.

${ }^{4}$ University of Sheffield, Sheffield University Management School, Sheffield, UK.

${ }^{5}$ United Arab Emirates University (UAEU), Department of Accounting \& Finance, Al Ain, UAE.

${ }^{*}$ These authors have recently changed affiliation. ${ }^{1}$ Henry was previously affiliated to the University of York, UK, while

${ }^{5}$ Samuel was previously affiliated to the DeMontfort University, UK.
} 


\section{Introduction}

International Financial Reporting Standards (IFRS) are presently adopted in one form or another in 166 jurisdictions around the world, including about 30 African countries. ${ }^{1}$ This widespread adoption may be due to the expected benefits of IFRS such as increased corporate transparency, enhanced cross-border comparability of financial reports and improved quality of financial reporting, among others. These potential benefits, perhaps, explain the considerable attention that IFRS have received from regulators and investors. The implementation of IFRS is also the focus of a growing body of research partly because it permits a shock-based research approach that minimises the endogeneity problems inherent in examining cross-sectional relations between the quality of financial reporting and firm performance.

Despite the growing lines of research on international reporting standards (Ball, 2006; Kettunen, 2017; Balsmeier \& Vanhaverbeke, 2018), the existing research which typically focuses on indirect measures of costs and benefits of IFRS reporting requirements has yielded mixed results, and largely ignores African markets. ${ }^{2}$ For instance, Houqe, Easton, and Zijl (2014) show that in France, Germany, and Sweden where investor protection is low, IFRS adoption enhanced information quality by significantly improving analyst forecast accuracy and dispersion. Jiao, Koning, Mertens, and Roosenboom (2012) replicate this finding in the European Union context. By contrast, Jeanjean \& Stolowy (2008) find that IFRS implementation in Australia, France, and the UK did not improve earnings quality since earnings management remained pervasive, especially in France. Thus, several important questions remain unanswered: Does IFRS adoption bring benefits in the African environment, characterised by relatively underdeveloped institutional infrastructure? Does the extent/nature of IFRS adoption matter? Does the level of financial constraint faced by firms and the commitment to the rule of law at the macro-level shape the benefits of IFRS adoption in Africa? The current paper addresses these questions by examining the impact of IFRS adoption by African countries on firm value.

\footnotetext{
${ }^{1}$ See list of countries that have adopted IFRS on the IFRS Foundation's website: https://www.ifrs.org/usearound-the-world/use-of-ifrs-standards-by-jurisdiction/\#1 [Accessed on $18^{\text {th }}$ May, 2018].

${ }^{2}$ A notable exception is Daske, Hail, Leuz, \& Verdi (2008) who explored the direct economic consequences (share liquidity, cost of capital, and Tobin's q) of IFRS adoption for 26 countries which included only one African country (South Africa).
} 
To assess the value relevance of IFRS, we focus on firm value because it is a fundamental and more direct way of assessing value creation or destruction in firms, which perhaps explain its broad application in accounting and finance research as a bottom-line performance measure (see, e.g. AgyeiBoapeah, 2018; Daske, Hail, Leuz, \& Verdi, 2008; Fauver, Hung, Li, \& Taboada, 2017). The notion is that the improved financial reporting associated with IFRS implementation may discourage self-seeking corporate managers from undertaking earnings management and, thus, lead to greater transparency and improved access to external finance. Impliedly, IFRS implementation has the potential to reduce firms' cost of capital and ultimately enhace firm value.

IFRS are also necessary when managers are not agency-motivated because market frictions may sometimes prevent firms from investing in good accounting practices that can increase shareholder value. Corporate managers may not have sufficient incentives to voluntarily invest in strong financial reporting practices as desired by minority shareholders because they bear the full costs but only reap part of the benefits from increased firm value. Accounting standards, particularly, IFRS enacted by a process of international consultation and adopted by governments can help overcome this friction by requiring firms to apply global accounting standards that are generally regarded to be of a higher quality. Consequently, IFRS may be beneficial to firms as they require or encourage managers to prepare comparatively better-quality financial statements, which they may not otherwise do.

However, other studies (Barth, Landsman, \& Lang, 2008; Pawsey, 2017) question the superiority of global standards over national generally accepted accounting principles (GAAP), as well as, whether the stringent implementation requirements and high compliance costs associated with IFRS are justified. For instance, Pawsey (2017) argues that IFRS impose incremental costs on firms by diverting management's attention and significant resources away from core business operations and investments towards understanding and managing the transition to the new financing reporting regime. Besides the one-off transition costs associated with moving from domestic standards to IFRS, some ongoing costs such as staff training and development to cope with complex regulations, as well as external consultancy and audit support to ensure compliance with greater disclosure requirements may also exist (Pawsey, 2017). Thus, the costs of IFRS implementation and compliance could outweigh any potential benefits, especially for firms domiciled in countries with strong local financial reporting standards, and thereby, 
reduce firm value or impact it insignificantly. Ultimately, the average effect of IFRS adoption on firm value is an open empirical question, which we attempt to answer in this study.

Our empirical analysis covers IFRS adoption in 7 African countries (namely; Botswana, Ivory Coast, Egypt, Ghana, Morocco, Nigeria, and South Africa) between 2000-2015. Our focus on the African market is significant because much of the IFRS literature focuses almost exclusively on the European (Houqe et al., 2014; Jiao et al., 2012), Australian (Pawsey, 2017), and Asian (Sato \& Takeda, 2017) institutional contexts, with the African context largely overlooked (Samaha \& Khlif, 2016). ${ }^{3}$ Meanwhile, the African continent characterised by a relatively underdeveloped financial reporting infrastructure (Elbannan, 2011; Lassou \& Hopper, 2016; Samaha \& Khlif, 2016) and insufficient local capacity and political leadership to support accountability reforms (Hopper, Lassou, \& Soobaroyen, 2017), could arguably reap more benefits from IFRS adoption.

Indeed, IFRS requirements are generally expected to yield higher dividends in countries with lower disclosure requirements and low financial reporting quality under national GAAP (Houqe, Monem, \& Zijl, 2016). There are, however, others (e.g. Chand \& White, 2007; Hopper et al., 2017; Mantzari et al., 2017) who argue that the implementation of IFRS has minimal or negative net benefits in developing countries because the standards are designed to serve the interest of powerful players in North America and Europe. Although most firms in the US (e.g. listed domestic companies) use US GAAP, it seems the US can exercise some influence in the IFRS standard-setting process (Bamber \& McMeeking, 2016; Botzem \& Quack, 2009). ${ }^{4}$ For instance, Bamber \& McMeeking (2016) document a positive bias towards the US in the standard-setting process of IFRS 7 Financial Instruments: Disclosures. They report that proposals from the US have greater relative influence, and US comments are more likely to be discussed and accepted than those from other parts of the world. Overall, the African continent represents an interesting context to investigate the efficacy of global standards set by a body influenced by interests from the developed world, particularly in Europe.

\footnotetext{
${ }^{3}$ In Samaha \& Khlif's (2016) review of the literature on the economic consequences of IFRS adoption in developing countries, only two firm-level studies related to African economies; i.e., Bova, Pereira, \& Welker (2012) and Elbannan (2011) all undertaking single-country studies. Bova et al. (2012) examined the Kenyan context while Elbannan (2011) investigated the Egyptian contexts.

${ }^{4}$ See Botzem and Quack (2009) for a detailed discussion of how the US together with the UK, and Canada have influenced the IASB with Anglo-American accounting traditions.
} 
Our study uncovers several new findings, and in the process, contributes to the literature in five important ways. First, we add to the growing literature that examines the value relevance of IFRS adoption by providing evidence of a positive relationship between IFRS implementation and firm value for African firms. By showing that investors (on average) value African firms more highly when the host country adopts IFRS, we contribute further empirical evidence that helps in resolving the mixed findings, often based on proxies for earnings quality and cost of capital. Our findings suggest that African firms reap significant net economic benefits from IFRS implementation. Second, our study is the first to analyse the economic consequences of IFRS for African firms within a cross-country framework. Besides providing more generalisable results, our empirical approach that combines firmand country-level variables allows for a more robust analysis that addresses endogeneity and selfselection concerns that plague most studies in this area. This is because the adoption of IFRS is largely exogenous to the individual firm as governments decide when and how to adopt IFRS at the national level. Hence, we examine the impact of an "exogenous" event on a firm-level outcome (firm value). Thus, we provide evidence to suggest that global standards, designed by a body dominated by Europeans, could still offer some benefits for African firms, perhaps, because local accounting standards in most African countries are relatively weak.

Third, we document significant variations in the benefits of adopting IFRS, as our results show that the benefits are greater when the adopting country is more committed to the rule of law. Thus, we offer novel evidence of the potential complementarity between IFRS adoption by African countries and a commitment to the rule of law. Perhaps, a strong rule of law is consistent with the presence of adequate enforcement mechanisms which incentivise managers to adhere to the pronouncements of the accounting standards. Fourth, we show that while both financially constrained and unconstrained African firms benefit from the implementation of IFRS, the gains are higher for the latter group of firms relative to the former. These results imply that the value derived from IFRS adoption may partly be due to improved access to external financing. Finally, we examine the value implications of full vis-à-vis partial/modified adoption of IFRS. While a partial adoption may allow African countries to modify the global standards to reflect their local circumstances, it could also water down some benefits of IFRS such as comparability and transparency of financial reports (Daske \& Gebhardt, 2006). Our findings 
support the latter view since IFRS implementation only has a significantly positive effect when African countries fully adopt them.

Collectively, our study contributes to the literature by not only documenting an overall net benefit of adopting IFRS by African countries but also highlighting a varying degree of success for IFRS implementation depending on the adopting country's commitment to the rule of law, the firms' levels of financing constraints, and the nature of adoption (full vs modified).

The rest of the paper is organised as follows. Section 2 reviews the African institutional environment, related literature, and formulates hypotheses. Section 3 describes the data and presents the methodology. Section 4 discusses the empirical findings and robustness tests, while Section 5 concludes the paper.

\section{Related literature and hypotheses development}

\subsection{The African institutional background}

The value relevance of accounting information is a function of the quality of accounting regulation, but also crucially depends on the institutional mechanisms in place to develop and enforce such regulations. Here, the role of capital markets, regulatory bodies and traditions, as well as, the rule of law cannot be over-emphasised. Industrialised economies such as the G8 nations are generally characterised by burgeoning capital markets, which enables listed firms to raise capital from individual and institutional investors. Such countries also tend to have the capabilities to develop robust regulatory infrastructure to support their market-oriented needs (Agyei-Boapeah \& Machokoto, 2018; Uddin \& Tsamenyi, 2005). Within this context, while quality financial reporting may be developed and strongly enforced, the underlying financial reporting infrastructure is largely designed to ensure efficiency in the allocation of investors' funds.

The African continent, on the other hand, is characterised by weak capital markets, with most firms depending more on families and banks and less on capital markets for financing needs (Tunyi \& Ntim, 2016; Chijoke-Mgbame et al., forthcoming). Thus, the relevance of financial reporting information in the African setting may be judged by its ability to address creditor needs sufficiently without being overly costly, rather than focusing on investor needs (Okike, 2004; Uddin \& Tsamenyi, 2005). 
However, most African countries base their regulations, including financial reporting framework, on long-established colonial traditions. This approach of wholesale adoption of foreign laws implies that most African countries do not fashion new regulations that take their unique circumstances into account (Elad, 2015; Okike, 2004). Okike (2004) notes that, by mimicking the UK Companies Act, the Nigerian Companies Act of 1968 failed to deal with several country-specific issues relating to economic and commercial development. Similarly, Uddin \& Tsamenyi (2005) suggest that, in Ghana, the IMF, World Bank, and Western capitalist states provided the technical infrastructure and organisational capacity to execute neo-liberal privatisation reforms, including the promotion of IFRS, with little regard for the peculiar Ghanaian setting. Elad (2015) further points out that the endorsement of IFRS by the IMF, World Bank, and other international donor agencies has legitimised IFRS across the African continent.

Although the literature seems to suggest that wholesale adoption of foreign regulations may be of limited value to African countries, the practice seems to continue (Uddin \& Tsamenyi, 2005). This is perhaps due to the limited technical capabilities in some African countries that constrain the development of local legislation (Okike, 2004), strong historical and colonial ties with European countries (Elad, 2015), and a strong reliance on multinational agencies such as IMF and World Bank for funding (Uddin \& Tsamenyi, 2005).

On the specific issue of the development of financial reporting infrastructure in Africa, Elad (2015) highlights two broad accounting systems - the Franco-German model and the Anglo-Saxon model - as dominating accounting practice and regulation on the African continent. The Franco-German accounting model is rule-based and is mostly adopted by African countries that are former colonies of France, Portugal and Belgium (e.g. Ivory Coast, Benin, Cameroon, Angola, Morocco, Tunisia, Algeria, etc.). Elad (2015) notes that this accounting model is less compatible with IFRS since it is "sociallyoriented" rather than "market-oriented". ${ }^{5}$ Expectedly, most non-IFRS adopters (e.g. Chad, Congo, Guinea) or partial/modified IFRS adopters (e.g., Cameroon, Morocco, Algeria, Angola) in Africa share this approach to financing reporting.

\footnotetext{
${ }^{5}$ According to Elad (2015, p.84-85), the Franco-German accounting model adopted by most Francophone African countries is "socially-oriented" since it focuses on protecting creditors and providing information for tax purposes. For instance, it requires expenses in the income statement to be grouped "by nature" (not "by function") in order to be able to measure an entity's total production and value-added in a particular year.
} 
On the other hand, former British or American colonies (e.g. Ghana, Nigeria, Botswana, South Africa, Egypt, Kenya, Zambia, Liberia, etc.) follow the Anglo-Saxon (judgmental) accounting model which is oriented towards decision making by investors (Nobes, 2003; Palea, 2018). The Anglo-Saxon accounting model is more consistent with IFRS and suits African countries with relatively wellfunctioning capital markets (e.g. South Africa). It is noteworthy that apart from Ivory Coast and Morocco, the rest of the countries in our sample (i.e., Ghana, Nigeria, Botswana, South Africa, and Egypt) share the Anglo-Saxon accounting tradition (see Table 1). Thus, most of our sample firms are operating within an institutional environment that traditionally welcomes the market-oriented (AngloSaxon) system of accounting, which underpins IFRS (Botzem \& Quack, 2009).

Another strand of the literature reports that the level of financial development, as well as the commitment to enforce enacted laws, may influence the efficacy of IFRS in some developing countries (e.g. Elbannan, 2011; Daske et al., 2013; Nnadi \& Soobaroyen, 2015). Most African countries are characterized by low levels of financial development, illiquid stock markets, ${ }^{6}$ underdeveloped local capital markets that are less integrated with international capital markets, high levels of corruption, low levels accountability and low commitment to the rule of law (Agyei-Boapeah \& Machokoto, 2018; Hillier, Hodgson, \& Ngole, 2016; Tunyi \& Ntim, 2016). Agyei-Boapeah \& Machokoto (2018) find that due to the underdevelopment of capital markets in most African countries, firms operating in this unique context tend to save most of their cash flows which enables them to finance investments internally. In terms of commitment to the rule of law, Figure 1 presents mean values of the Rule of Law index for all countries for which World Governance Indicators (WGI) data is available (see Kaufmann, Kraay, \& Mastruzzi, 2011), grouping these countries by continent. We use data for the period covering our study (2000-2015). As shown in the Figure, over our sample period (2000-2015), Africa underperforms the rest of the world in terms of adherence to the rule of law. This suggests that when most African countries adopt IFRS (accounting laws), they may be less committed to its enforcement, and consequently reap little benefits from them.

\section{[PLEASE INSERT FIGURE 1 HERE]}

${ }^{6}$ Illiquid stock markets impede the establishment of fair values for assets (i.e., fair value accounting)—one of the cornerstones of IFRS. 
Given the unique institutional context and challenges facing Africa, some studies have explored the benefits of IFRS adoption within this setting. Hillier et al. (2015), for example, explore the valuerelevance of IFRS adoption using a sample of 347 firms across Botswana, Egypt, Kenya, Morocco, and South Africa over the 2002-2009 period. Their results were inconclusive as book values were found to be more value-relevant, while earnings were less value-relevant post-IFRS adoption. Elbannan (2011) investigates whether IFRS adoption improves earnings quality amongst Egyptian firms. They find that IFRS adoption does not decrease the incidence of earnings management amongst Egyptian firms. Elbannan (2011) argues that the lack of enforcement by regulators, as well as, inadequate training of practitioners impaired the ability of IFRS to improve earnings quality in this unique setting.

In another cross-country study exploring the benefits of IFRS adoption across 34 African countries over 20 years, Nnadi and Soobaroyen (2015) report that full adoption of IFRS is negatively associated with net foreign direct investments (FDI). Instead, they find that a country's basic legal and socioeconomic factors including the rule of law, legal system, and level of corruption are more critical in attracting FDI in Africa than merely adopting IFRS. Nnadi and Soobaroyen (2015) advocate for African countries to prioritise more critical institutional reforms such as legal and anti-corruption reforms ahead of accounting reforms (such as IFRS adoption). In summary, these studies question the relevance of IFRS for African firms with anecdotal evidence suggesting that the absence of efficient enforcement mechanisms and well-functioning capital markets could be responsible for the failure of IFRS to improve financial reporting quality in this context.

As noted earlier, strong institutions and enforcement mechanisms tend to complement the efficacy of IFRS (see, for example, Elbannan, 2011; and Nnadi \& Soobaroyen, 2015). While the African continent is generally regarded as having weak institutions, it is important to note that there is considerable heterogeneity amongst countries in terms of the effectiveness of underlying national institutions (Agyei-Boapeah \& Machokoto, 2018; Tunyi, Agyei-Boapeah, Areneke, \& Agyemang, 2019). As shown in Figure $2,{ }^{7}$ for example, Nigeria and Ivory Coast have a very low (negative) commitment to the rule of law. Similarly, Egypt and Morocco report similar low commitments to the

\footnotetext{
${ }^{7}$ Figure 2 presents mean values of the Rule of Law index (see Kaufmann et al., 2011) for all countries in our sample. The data used to derive mean values covers our sample period (2000-2015).
} 
rule of law, which are again negative but considerably higher than the levels achieved by Ivory Coast and Nigeria. However, the mean Rule of Law index is positive in Botswana, South Africa and Ghana; with Botswana having a higher score than the average for countries in North American and broadly comparable to the European average reported in Figure 1.

To the extent that the rule of law underpins and reflects other institutional factors including the level of financial development, accountability, and commitment to accounting regulations, it is plausible to expect the benefits of IFRS adoption to vary significantly across the African countries in our sample. Countries such as South Africa and Ghana with relatively well-functioning capital markets and a stronger commitment to the rule of law (and by extension, accounting regulations) may find IFRS to be more relevant than their other counterparts (e.g. Nigeria, Ivory Coast, Egypt, etc.).

\section{[PLEASE INSERT FIGURE 2 HERE]}

Finally, it is plausible not to expect radical changes in the accounting traditions of countries in our sample, since traditions hardly change, and if they do, they only change marginally over a long period. In fact, the median Rule of Law index for African countries in 2000 was -0.713 , and this figure stood at -0.721 at the end of 2015. This suggests that the legal (and institutional) environment in Africa has remained largely the same over our sample period (2000-2015). Given a relatively constant institutional environment in Africa, we contend that our empirical analysis better captures the impact of IFRS adoption in Africa, with little confounding effects from changes in the institutional setting.

\subsection{Theory, empirical literature, and hypotheses development}

A goal of the International Accounting Standards Board (IASB) is to develop an internationally accepted set of high-quality financial reporting standards (Barth et al., 2008). In achieving this goal, the IASB through a due process, which draws on the technical expertise of professionals from several countries (Hopper et al., 2017), issues standards (e.g. IFRS) that remove some of the allowable accounting alternatives and require accounting measurements that better reflect a firm's economic performance and position. If these actions by the global standard setters can limit management's opportunistic discretions in determining accounting values, financial reporting quality could increase, leading to reduced information asymmetry and increased investor confidence. From this perspective, 
we posit that financial reports based on IFRS may be of a higher quality than those based on domestic standards.

Consistent with this line of reasoning, Barth et al. (2008) find that firms in countries that adopt global standards tend to produce higher quality accounting reports (e.g. less earnings management, more timely loss recognition) than do a matched sample of firms applying domestic standards. Daske \& Gebhardt (2006) examine the quality of financial statements of Australian, German, and Swiss firms that adopt IFRS and document an increase in disclosure quality in all three countries. They also find their results to hold for both firms that voluntarily adopted IFRS as well as for the mandatory adopters. These findings imply that the adoption of IFRS could prove beneficial to firms and their investors by increasing the quality of information disclosures.

Another strand of the literature relates IFRS adoption to the cost of capital (Florou \& Kosi, 2015; Houqe et al., 2016; Kim et al., 2014). The main argument here is that by adopting a common set of accounting standards, the comparability of financial reports across national borders should facilitate cross-border capital flows and ease the firms' financing constraints. Moreover, with improvement in information quality through higher disclosure requirements under IFRS, investors are better able to monitor managers, and therefore, demand a lower risk premium. Houqe et al. (2016) find that IFRS adoption by firms in New Zealand is associated with a significantly lower cost of equity. Based on a large sample of firms across 34 countries, Kim et al. (2014) also document a significantly lower cost of equity for IFRS adopters relative to non-adaptors. Similarly but focusing on the bond markets, Florou \& Kosi (2015) show a positive effect of IFRS adoption on debt financing. They find IFRS adopters to enjoy increased access to bond markets and a reduction in their cost of bonds by about 37 basis points.

Collectively, to the extent that improved information quality and lower cost of capital enhance firm value, we expect an increase in firm value following the adoption of IFRS. Given the importance of the link between the quality of information disclosure and firm value, it is somewhat surprising that this issue has been largely overlooked in the extant empirical literature. A notable exception is Sato \& Takeda (2017), who applies the event study methodology on a sample of Japenese firms and find higher stock prices for IFRS adopters around the announcement date of IFRS adoption. They further find a positive market reaction to IFRS adoption with this effect being higher for firms operating in a weak 
governance environment. Based on the above discussions, we expect the adoption of IFRS by African countries, generally believed to have weak governance/institutional structures, to result in significantly positive net benefits for the firms domiciled therein. Accordingly, Hypothesis 1 (H1) is formulated below for testing:

H1: The adoption of IFRS by African counties is associated with an increase in firm value.

\subsection{The moderating effect of country-level rule of law}

Although firms operating in African economies are likely to benefit from the implementation of IFRS, we do not expect the economic benefits of IFRS adoption to be uniform across all firms and countries. Prior studies suggest that the economic benefits of IFRS adoption depend on the institutional environment of the adopting countries (Christensen, Hail, \& Leuz, 2013; Daske et al., 2008; Sato \& Takeda, 2017). We, therefore, argue that where there is a lack of enforcement of accounting standards, the benefits of higher information quality and lower cost of capital arising from higher quality accounting standards may not materialize (Beiruth et al., 2017). By contrast, where both the political environment prevailing in a country, as well as, the corporate culture promotes adherence to accounting standards, this makes it conducive for whatever benefits associated with higher quality accounting standards to materialise.

Following this line of reasoning and presuming a correlation between a national culture of commitment to the rule of law and enforcement of accounting standards, we posit that the legal environment (mainly, commitment to the rule of law) prevailing in a country is a crucial mediating factor which determines the extent of benefits that firms in African countries can reap from IFRS implementation. Specifically, we expect any potential positive effect of IFRS on firm value to be magnified in an environment where there is a stronger commitment to the rule of law, to possibly permit strict enforcement of the high-quality global accounting standards. Arguably, the commitment to the rule of law by African countries may offer a form of assurance or guarantee to foreign investors that they (the African countries) are serious about producing high-quality accounting information 
comparable to global standards. Such a guarantee to investors, all else equal, should subsequently lead to higher benefits of IFRS implementation. This leads us to our second hypothesis (H2) below:

H2: The positive effect of IFRS adoption on firm value is higher in countries with a greater commitment to the rule of law.

\subsection{The moderating effect of firm-level financial constraint}

Similarly, at the firm-level, the benefits of IFRS may vary according to the firm's ability to access external finance. Since a key benefit of IFRS adoption is the reduction in the cost of obtaining external finance via an improvement in the information environment (Kim et al., 2014; Florou \& Kosi, 2015; Sato \& Takeda, 2017), we expect the adoption of IFRS to yield asymmetrically higher benefits for financially constrained firms than their unconstrained counterparts. For instance, when a country adopts IFRS, individual firms with financing difficulties may be more willing to embrace and implement the standards more seriously to signal their commitment to higher global accounting standards. This could reduce the cost of capital of such constrained firms. In other words, these financially constrained firms may be viewed as "serious IFRS adopters", and thus, have a higher chance of benefiting from IFRS adoption.

We base our argument in this subsection on the work of Daske, Hail, Leuz, \& Verdi (2013) who classify firms into "label" and "serious" adopters. Daske et al. (2013) contend that while "label" adopters only adopt IFRS in name, "serious" adopters make real efforts to implement the spirit of the standard. They find "serious" adopters to be associated with higher liquidity and lower cost of equity than their "label" adopter counterparts. Baboukardos \& Rimmel (2014) suggest that firms with high levels of compliance to IFRS tend to have their goodwill information to be value-relevant. If, indeed, investors value IFRS and reward adopters with a lower cost of capital, it is plausible that financially constrained firms may enhance their external financing prospects by showing a serious commitment to IFRS implementation. Financially unconstrained firms, on the other hand, might not need IFRS adoption as a credible signalling device as they already have better access to capital markets at a reasonable cost. Thus, unconstrained firms are more likely to be "label" adopters, repeating relatively 
lower IFRS benefits than the financially constrained "serious" adopters. Accordingly, we formulate our final hypothesis (H3) below:

H3: The positive effect of IFRS adoption on firm value is higher for financially constrained firms than for other firms.

\section{Data and methods}

\subsection{Data}

We begin our analyses by hand-collecting information on IFRS adoption (e.g. date, extent, etc.) from 2000 to 2015 for all African countries with the available stock price and financial data in Thomson Financial's Datastream databases. Our primary sources of information on IFRS adoption are reports from the IFRS Foundation on the jurisdictional profile of countries, local accounting regulators, and prior studies (e.g. Nnadi \& Soobaroyen, 2015). We identify the year in which a country adopts IFRS and the extent/nature of adoption in place (full vs partial/modified).

For our sample countries, we collect financial data for the firms from Datastream. Following standard practice in the literature (e.g. Agyei-Boapeah, 2015), we exclude those firms in the financial and utility sectors that tend to be heavily regulated. Further, firms with missing observations as well as those with more than $100 \%$ asset growth are dropped. To reduce the effect of other confounding events, we restrict our analyses to the 5 years before and after the year of IFRS adoption. These restrictions lead to a final sample that makes it possible to undertake an analysis based on a $[-5 \mathrm{yr},+5 \mathrm{yr}]$ year window. Panel A of Table 1 shows the sample construction process. This process generates a final sample of 534 firms (4,749 firm-year observations) from seven African countries; namely, Botswana, Ivory Coast, Egypt, Ghana, Morocco, Nigeria and South Africa. Our sample countries are geographically diverse, with representations from the Northern, Southern and Western parts of the African continent.

\section{[PLEASE INSERT TABLE 1 HERE]}

As can be seen from Table 1 (Panel B), the distribution of the observations per country varies widely. South Africa has the largest number of observations (4,027), and Botswana has the smallest 
number of observations (15). The table also shows no concentration of IFRS adoption in any single year. Panel A of Table 2 presents descriptive statistics for the firm- and industry-level measures of corporate value and the control variables used in this study. A key observation from the statistics is that firm value, as measured by Tobin's $q$, is significantly higher in the post-IFRS periods relative to the pre-IFRS years. This offers some early evidence in support of our primary hypothesis (H1). The correlation matrix in Panel B also shows a minimal correlation among the explanatory variables utilised in this study. This suggests that multicollinearity is not a major concern for our analyses.

\section{[PLEASE INSERT TABLE 2 HERE]}

\subsection{Methodology}

We test the average effect of IFRS adoption on firm value by using a difference-in-difference (DID) design and regress Tobin's $q$ on Post, a dummy variable that captures the post-IFRS adoption period. This approach, which is commonly used in the literature (Agyei-Boapeah, 2015; Fauver et al., 2017), implicitly takes as the benchmark group all firms from countries that have not adopted IFRS as of a particular time. While this approach is appropriate, a more compelling methodology would be to follow Christensen et al. (2013) and compare a group of firms in countries adopting IFRS (treatment group) with those in non-adopting countries (control group). We are, however, unable to adopt this approach due to data availability. Specifically, after applying the relevant data filters, all the potential firms in the control group (non-IFRS adopting African countries) dropped from our final sample. We, therefore, relied on similar procedures in Fauver et al., (2017) to compare the firm value in the post-IFRS period with its pre-IFRS period.

To mitigate the effect of omitted variable bias, we control for other time-varying firm- and industrylevel variables used in previous studies to explain firm value (Doidge, Karolyi, \& Stulz, 2004; Fauver et al., 2017; Gompers, Ishii, \& Metrick, 2010). The control variables for the baseline regression model are as follows: Cash flow, measured as the ratio of net cash flow from operations to total assets; Sales growth, the current year's sales divided by the previous year's sales minus one; Size, the log of total assets; Leverage, total debt divided by total assets; Capital expenditure (Capex), capital expenditures 
divided by total assets; and Property, plant, and equipment (PPE), the ratio of PPE to total assets. Also, our model controls for a time trend in Tobin's $q$ in an industry by including, Industry Median $Q$, defined as the annual median Tobin's $q$ in the firm's industry. All variables used in the study are defined in Appendix A. We winsorise all firm-level variables at the bottom and top $1 \%$ to mitigate the effect of outliers on our regression results.

Our baseline model for testing the effect of IFRS adoption on firm value is specified as follows:

$$
Q_{i j t}=\alpha+\beta \text { Post }_{I F R S_{i j t}}+\theta X_{i j t-1}+\varepsilon_{i j t}
$$

where $Q_{i j t}$ is Tobin's $q$ for firm $i$ in country $j$ at time $t ; \alpha$ is a constant; $\beta$ and $\theta$ are coefficients to be estimated; Post-IFRS $S_{i j t}$ is a dummy variable that takes the value of one for the post-IFRS adoption period and zero otherwise; $X_{i j t-1}$ is a vector of the determinants of firm value explained above; and $\varepsilon_{i j t}$ is an error term. Our variable of interest in Eq. (1) is $\beta$, the coefficient for the post-IFRS adoption dummy. A positive (negative) coefficient on $\beta$ will be consistent with an increase (a decrease) in firm value. All our regressions are estimated using the fixed-effect technique to help minimise the possibility of making biased inferences due to the omission of any time-invariant variable which may be correlated with our included explanatory variables. ${ }^{8}$

\section{Results and discussions}

\subsection{The effect of IFRS adoption on firm value}

We begin our empirical analysis by examining the impact of IFRS implementation on firm value. The panel regression (with year and firm fixed effects) results are presented in Table 3. Columns (1)-(6) present the results testing Hypothesis 1 (H1). Column (1) is based on the baseline model that includes only our variable of interest (Post-IFRS) and excludes control variables. Column (2) is our full model which includes the control variables and utilises the main sample (i.e. the $[-5 \mathrm{yr},+5 \mathrm{yr}]$ sample). For robustness, we repeat the test in Column (2) in Columns (3)-(6) but for other event windows/samples; namely, [-4yr, +4yr], [-3yr, +3yr], [-2yr, +2yr] and [-1yr, +1yr].

${ }^{8}$ Our key conclusions are robust to OLS and random-effect estimations that allow us to use country dummies to directly control for country-specific effect. 
We find that the coefficient on Post-IFRS is positive and significant across all the models, indicating that Tobin's $q$ increases following IFRS adoption. Importantly, the effect is also economically significant. For example, the results in Column (2) suggest that Tobin's $q$ increases, on average, by $22.2 \%$ following implementation of IFRS in our sample African countries. ${ }^{9}$ To the extent that higher profits increase firm value, this finding is in line with Ali et al. (2016). For the control variables, the results show that Tobin's $q$ is higher among African firms with more cash holdings and in industries with higher Tobin's $q$. However, Tobin's $q$ is lower for larger firms and those with more capital investments and higher levels of Property, Plant and Equipment. Finally, sales growth and leverage are insignificantly related to Tobin's $q$. These findings are broadly in line with prior studies (e.g. Fauver et al., 2017; Gompers et al., 2010).

\section{[PLEASE INSERT TABLE 3 HERE]}

\subsection{The moderating effect of rule of law on the IFRS adoption-firm value nexus}

Column (7) of Table 3 presents our analysis of Hypothesis 2 - i.e., the moderating role of rule of law on the relationship between IFRS adoption and firm value. We undertake this analysis by modifying our baseline model in Eq. (1) to include a variable for the rule of law and an interaction term of the rule of law and IFRS adoption (Post-IFRS x Rule of law). The coefficient $\left(\beta_{3}\right)$ on the Post-IFRS $\mathrm{x}$ Rule of law is the parameter of interest for this analysis.

$$
\begin{gathered}
Q_{i j t}=\alpha+\beta_{1} \text { Post }_{\text {IFRS }} i j t \\
\\
\varepsilon_{i j t}
\end{gathered}
$$

The coefficient on Post-IFRS x Rule of law in Column (7) of Table 3 is positive and statisticaslly significant, which suggest that the effect of IFRS adoption on firm value is substantially higher in African environments with a greater commitment to the rule of law. The coefficient of the individual impacts of Post-IFRS and the rule of law on firm value are also positive and significant.

${ }^{9}$ The $22.2 \%$ is computed by dividing the beta value of 0.358 by the average value (1.613) of Tobin's q for the sample. The results are qualitatively similar when we use a balanced sample (i.e., firms that appear in both the pre- and post-IFRS period). For example, the balanced sample for [-5yr, $+5 \mathrm{yr}]$ yields a post-IFRS increase of $19.8 \%$ in Tobin's $q$, compared to the $22.2 \%$ reported for the unbalanced sample. 


\subsection{The impact of financing constraint on the IFRS adoption-firm value nexus}

In this section, we test Hypothesis (H3) which posits that IFRS adoption is more beneficial for firms facing a higher degree of financial constraint. To test this prediction, we re-run our baseline model for a subsample of firms facing "High" vs "Low" risk of financial constraints. For robustness, we also present results using three alternative proxies of financial constraints - firms' age, size, and asset liquidity.

The results reported in Columns (1) and (2) of Table 4 show that, while both young and mature firms experience significant increases in their Tobin's $q$ following IFRS adoptions, the impact is greater for younger firms relative to mature firms (i.e. betas of $0.442 \mathrm{vs} 0.308$ ). These findings imply that the implementation of IFRS is more beneficial for African firms that are likely to be financially constrained. Similar conclusions can be drawn based on Columns (3) and (4), where the effect of IFRS adoption is higher for smaller relative to larger firms (betas of 0.312 vs 0.259 ). Finally, the coefficient on PostIFRS is 0.615 (significant at the $1 \%$ level) for firms with low-asset liquidity (i.e. high risk of financial constraints). This compares with a value of 0.232 (also significant at $1 \%$ level) for firms of high-asset liquidity (i.e. low financial constraints). These results suggest that the positive impact of IFRS adoption on Tobin's $q$ for firms with low-asset liquidity is larger than that of firms of high-asset liquidity.

\section{[PLEASE INSERT TABLE 4 HERE]}

Collectively, our findings so far are consistent with $\mathrm{H} 3$ and imply that the implementation of IFRS by African countries tends to be more valuable for firms that face binding external financial constraints (i.e., young and small firms with low asset liquidity), but are contrary to results in Beiruth et al. (2017). One potential explanation for our finding is that IFRS adoption (i.e., improved financial reporting) reduces information asymmetry between firms and their stakeholders, and this leads to improved access to external finance at more favourable terms.

\subsection{Robustness and further analysis}

So far, we have focused on Tobin's $q$ as a proxy of firm value. We now consider the sensitivity of our finding to alternative definitions of firm value. Table 5 reports these robustness results. In Column (1), 
we proxy for firm value using the ratio of market value to book equity, while Columns (2) and (3) utilise return on assets (ROA) and return on equity (ROE), respectively. Columns (1)-(3) of Table 5 show qualitatively similar results to those reported earlier in Table 3. The coefficient on Post-IFRS continues to be positive and significant at $1 \%$ significance levels in all cases, suggesting that firm value increases for African firms following IFRS adoption irrespective of the proxy used. Relatedly, we test the benefits of IFRS by studying its impact on market liquidity (proxied by bid-ask spread) and find that it significantly reduces the bid-ask spread [see Columns (4) of Table 5]. This finding is in line with Christensen et al. (2013) and our main conclusion that African firms derive significant benefits from adopting IFRS.

\section{[PLEASE INSERT TABLE 5 HERE]}

Next, we re-test $\mathrm{H} 3$ using an interaction term rather than splitting the sample into firms facing high vs low financial constraints. Using this approach helps to directly ascertain the incremental value of IFRS adoption conditional on financial constraints (i.e., the firm being young or small or having low liquidity assets). As can be seen in Columns (1)-(3) of Table 6, the conclusions drawn from Table 4 (by splitting the sample) remain unchanged. Specifically, Table 6 shows that that financially constrained firms (young, small, and low asset liquidity firms) have significantly higher Tobin's $q$ than financially unconstrained firms (mature, large, and high asset liquidity firms). Columns (4)-(5) of Table 6 present analyses based on the firms' levels of external relations. If, indeed, IFRS supports international business and global capital market integration (DeFond, Hu, Hung, \& Li, 2011), then, it is plausible to expect firms with better external relations (e.g. more foreign shareholders and/or foreign sales) to derive more benefits from IFRS adoption. Columns (4)-(5) of Table 6 show results that are consistent with this expectation. $^{10}$

\section{[PLEASE INSERT TABLE 6 HERE]}

Also, we assess whether our results are sensitive to the nature/extent of IFRS adoption (i.e. full vs partial/modified implementation). While all our sample countries fully adopted IFRS in its entirety, Ivory Coast and Egypt implemented a partial/modified version of IFRS. We, therefore, repeat our

\footnotetext{
${ }^{10} \mathrm{We}$ are grateful to two anonymous reviewers for suggesting most of the additional analyses in this section.
} 
analysis for the sub-samples of "full adopters" and "modified adopters". The results for this analysis, which are reported in Columns (1) and (2) of Table 7, show a positive impact of IFRS on Tobin's $q$ for both "full adopters" and "modified adopters", although the result for "modified adopters" lacks statistical significance at the conventional levels. These results suggest that our earlier finding of significant increases in firm value following IFRS adoption may be restricted to only African countries that "wholly" adopt IFRS without any modifications. Perhaps, investors interpret IFRS modifications by African countries as attempts to water down the stringent requirements of the standards.

Next, we examine the sensitivity of the results to the accounting tradition of the adopting country. Since countries with Anglo-Saxon accounting traditions generally believe in market-oriented accounting (Elad, 2015), they may benefit more from adopting IFRS since their systems are more compatible with IFRS. The results in Columns (3) and (4) of Table 7 support this view. The analysis based on the legal environment of the adopting country, in Columns (5) and (6), also supports the conjecture that IFRS is more beneficial when adopted within strong legal environments where laws are likely to be enforced.

Finally, we conduct a single-country analysis for those countries that have a relatively larger sample size to enable meaningful regressions (Nigeria, Egypt, and South Africa). As can be seen in Columns (7)-(9), these analyses suggest that IFRS adoption significantly increases firm value for South African firms but not for Nigerian or Egyptians firms. These results are not surprising since South Africa has a relatively more developed capital market, therefore, it is likely to benefit from a market-oriented accounting law such as IFRS. Nigeria adopted IFRS quite late (in 2012) while Egypt adopted a modified version of IFRS, and these peculiarities may explain why IFRS does not significantly benefit the firms in these two countries. However, for our analysis of the remaining African countries with small sample sizes [in Column (10)], we find evidence of a significant association between IFRS adoption and Tobin's $q$. This finding suggests that our key conclusion of IFRS adoption driving firm value is not restricted to South Africa but applies in countries such as Ghana and Botswana with decent capital markets and political governance.

[PLEASE INSERT TABLE 7 HERE] 


\section{Conclusions}

This study examines the effect of the adoption of IFRS in African countries over the period 20002015. We find a robust and significant positive impact of the adoption of IFRS on firm value, especially when IFRS is fully implemented without any modifications. Another observation is that the positive impact of IFRS adoption on firm value is more pronounced in African countries with a greater commitment to the rule of law and also among firms that are more likely to face binding external financial constraints.

This article provides several contributions to the accounting, finance and strategy literature. First, it contributes to the IFRS implementation literature (Houqe et al., 2016; Kettunen, 2017; Balsmeier \& Vanhaverbeke, 2018) by deepening our understanding of the range of benefits that firms derive from the implementation of IFRS. Our results based on data from African firms demonstrate that by fully implementing IFRS, firms accrue more benefits than those arising from partial or modified adoption. Second, this paper adds to the current literature which suggests that by responding to formal and informal institutions (including transparency-enhancing regulations) in emerging markets, firms can deliver superior outcomes (Peng et al., 2008). We demonstrate that formal institutional arrangements rather than informal in terms of the reporting standards (i.e., codified and fully implemented) are more likely to deliver superior outcomes for African firms. In addition, this study contributes to strategy research by showing that firms' fully, partial or modified adoption can provide a range of benefits. This article represents one of the first empirical studies examining the different outcome of the adoption of IFRS on firm value in the African context.

Regarding managerial and policy implications, the study suggests that IFRS adoption (i.e., improved financial reporting) may deliver more benefits in financial constraint environments by possibly reducing information asymmetry between firms and their stakeholders, and enhancing access to external financing at more favourable terms. To policymakers at the national level, this study implies that full implementation of IFRS delivers superior performance for African firms. Moreover, a commitment to the rule of law seems to complement IFRS implementation; thus, countries adopting 
IFRS should endeavour to strengthen their legal institutions if they are to derive significantly higher benefits from IFRS implementation.

Despite these findings, there are some limitations. First, our study focused on only African listed firms. Most African firms are unlisted and tend to be very small. There is the need for new lines of research on whether adopting higher reporting standards are beneficial to such firms. This extension could go a long way in influencing and shaping public policy on reducing information asymmetry and improving disclosure. Another area of future research would be a comparative study of listed firms in Africa and firms elsewhere in the emerging world to see whether the benefits vary across countries or regions. Our study is also limited in terms of the period (2000-2015) and the sample countries (7 African countries). There is the need for an examination of this issue over several decades and using a sample that covers more African countries to ensure that the results are more generalisable. Finally, data limitation did not permit to adopt a full difference-in-difference methodology which compares firms in African countries adopting IFRS with their counterparts in non-IFRS adopting African countries. Future studies can re-examine the issue using this more compelling approach.

\section{Acknowledgements}

We are very grateful to the Editor, Sumit K. Lodhia, and two anonymous reviewers for their helpful comments and suggestions. All error and omissions, however, remain ours.

\section{References}

Agyei-Boapeah, H. (2015). Cross-border acquisitions and financial leverage of UK acquirers. Accounting Forum, 39(2), 97108. https://doi.org/10.1016/j.accfor.2015.03.002

Agyei-Boapeah, H. (2019). Foreign acquisitions and firm performance: The moderating role of prior foreign experience. Global Finance Journal. 42, 100415. https://doi.org/10.1016/j.gfj.2018.02.001

Agyei-Boapeah, H., \& Machokoto, M. (2018). Allocation of internally generated corporate cash flow in Africa. Journal of Accounting in Emerging Economies, 8(4), 495-513. https://doi.org/10.1108/jaee-10-2017-0099

Ali, A., Akbar, S., \& Ormrod, P. (2016). Impact of international financial reporting standards on the profit and equity of AIM listed companies in the UK. Accounting Forum, 40, 45-62. http://dx.doi.org/10.1016/j.accfor.2015.12.001

Baboukardos, D., \& Rimmel, G. (2014). Goodwill under IFRS: Relevance and disclosures in an unfavorable environment. Accounting Forum, 38, 1-17. http://dx.doi.org/10.1016/j.accfor.2013.11.001

Bamber, M., \& McMeeking, K. (2016). An examination of international accounting standard-setting due process and the implications for legitimacy. British Accounting Review, 48(1), 59-73. https://doi.org/10.1016/j.bar.2015.03.003

Barth, M. E., Landsman, W. R., \& Lang, M. H. (2008). International accounting standards and accounting quality. Journal of Accounting Research, 46(3), 467-498. https://doi.org/10.1111/j.1475-679X.2008.00287.x

Beiruth, A. X., Favero, L. P. L, Murcia, F. D. R., de Almeida, J. E. F., \& Brugni, T. (2017). Structural changes in covenants through the adoption of IFRS in Brazil. Accounting Forum, 41, 147-160. 
http://dx.doi.org/10.1016/j.accfor.2017.06.004

Botzem, S., \& Quack, S. (2009). Limits to Anglo-American accounting? Reconstructing the history of the International Accounting Standards Committee: A review article. Accounting, Organizations and Society. https://doi.org/10.1016/j.aos.2009.07.001

Bova, F., Pereira, R., \& Welker, M. (2012). The Determinants and Consequences of Heterogeneous IFRS Compliance Levels Following Mandatory IFRS Adoption: Evidence from a Developing Country. Journal of International Accounting Accounting Research, 11(1), 83-111. https://doi.org/10.2308/jiar-10211

Chand, P., \& White, M. (2007). A critique of the influence of globalization and convergence of accounting standards in Fiji. Critical Perspectives on Accounting, 18(5), 605-622. https://doi.org/10.1016/J.CPA.2006.05.006

Chijoke-Mgbame, M., Agyenim Boateng, \& Mgbame, C. O. (2020). Board Gender Diversity, Audit Committee and Financial Performance: Evidence from Nigeria. Accounting Forum, forthcoming.

Christensen, H. B., Hail, L., \& Leuz, C. (2013). Mandatory IFRS reporting and changes in enforcement. Journal of Accounting and Economics, 56, 147-177.

Daske, H., \& Gebhardt, G. (2006). International financial reporting standards and experts' perceptions of disclosure quality. Abacus, 42(3-4), 461-498. https://doi.org/10.1111/j.1467-6281.2006.00211.x

Daske, H., Hail, L., Leuz, C., \& Verdi, R. (2008). Mandatory IFRS reporting around the world: Early evidence on the economic consequences. Journal of Accounting Research, 46(5), 1085-1142. https://doi.org/10.1111/j.1475679X.2008.00306.X

Daske, H., Hail, L., Leuz, C., \& Verdi, R. (2013). Adopting a Label: Heterogeneity in the Economic Consequences Around IAS/IFRS Adoptions. Journal of Accounting Research, 51(3), 495-547. https://doi.org/10.1111/1475-679X.12005

DeFond, M., Hu, X., Hung, M., \& Li, S. (2011). The impact of mandatory IFRS adoption on foreign mutual fund ownership: The role of comparability. Journal of Accounting and Economics, 51(3), 240-258. https://doi.org/10.1016/j.jacceco.2011.02.001

Doidge, C., Karolyi, G. A., \& Stulz, R. M. (2004). Why are foreign firms listed in the U.S. worth more? Journal of Financial Economics, 71(2), 205-238. https://doi.org/10.1016/S0304-405X(03)00183-1

Elad, C. (2015). The development of accounting in the Franc zone countries in Africa. International Journal of Accounting, 50(1), 75-100. https://doi.org/10.1016/j.intacc.2014.12.006

Elbannan, M. A. (2011). Accounting and stock market effects of international accounting standards adoption in an emerging economy. Review of Quantitative Finance and Accounting, 36(2), 207-245. https://doi.org/10.1007/s11156-010-01761

Fauver, L., Hung, M., Li, X., \& Taboada, A. G. (2017). Board reforms and firm value: Worldwide evidence. Journal of Financial Economics, 125(1), 120-142. https://doi.org/10.1016/j.jfineco.2017.04.010

Florou, A., \& Kosi, U. (2015). Does mandatory IFRS adoption facilitate debt financing? Review of Accounting Studies, 20 , 1407-1456. https://doi.org/10.1007/s11142-015-9325-Z

Gompers, P. A., Ishii, J., \& Metrick, A. (2010). Extreme Governance: An Analysis of Dual-Class Firms in the United States. Review of Financial Studies, 23(3), 1051-1088. https://doi.org/10.1093/rfs/hhp024

Hillier, D., Hodgson, A., \& Ngole, S. (2016). IFRS and Secrecy: Assessing Accounting Value Relevance Across Africa. Journal of International Financial Management \& Accounting, 27(3), 237-268. https://doi.org/10.1111/jifm.12043

Hopper, T., Lassou, P., \& Soobaroyen, T. (2017). Globalisation, accounting and developing countries. Critical Perspectives on Accounting, 43, 125-148. https://doi.org/10.1016/J.CPA.2016.06.003

Houqe, M. N., Easton, S., \& Zijl, T. Van. (2014). Does mandatory IFRS adoption improve information quality in low investor protection countries? Journal of International Accounting , Auditing and Taxation, 23, 87-97.

Houqe, M. N., Monem, R. M., \& Zijl, T. van. (2016). The economic consequences of IFRS adoption: Evidence from New Zealand. Journal of International Accounting, Auditing and Taxation, 27, 40-48. https://doi.org/10.1016/J.INTACCAUDTAX.2016.10.001

Jeanjean, T., \& Stolowy, H. (2008). Do accounting standards matter? An exploratory analysis of earnings management before and after IFRS adoption. J. Account . Public Policy, 27, 480-494. https://doi.org/10.1016/j.jaccpubpol.2008.09.008

Jiao, T., Koning, M., Mertens, G., \& Roosenboom, P. (2012). Mandatory IFRS adoption and its impact on analysts ' forecasts. International Review of Financial Analysis, 21, 56-63. https://doi.org/10.1016/j.irfa.2011.05.006

Kaufmann, D., Kraay, A., \& Mastruzzi, M. (2011). The Worldwide Governance Indicators: Methodology and Analytical Issues. Hague Journal on the Rule of Law, 3(02), 220-246. https://doi.org/10.1017/S1876404511200046

Kim, J.-B., Shi, H., \& Zhou, J. (2014). International Financial Reporting Standards, institutional infrastructures, and implied cost of equity capital around the world. Review of Quantitative Finance \& Accounting, 42, 469-507. https://doi.org/10.1007/s11156-013-0350-3

Lassou, P. J. C., \& Hopper, T. (2016). Government accounting reform in an ex-French African colony: The political economy of neocolonialism. Critical Perspectives on Accounting, 36, 39-57. https://doi.org/10.1016/J.CPA.2015.10.006 
Mantzari, E., Sigalas, C., \& Hines, T. (2017). Adoption of international financial reporting standards by Greek non-listed companies: The role of coercise and hegemonic pressures. Accounting Forum, 41, 185-205. http://dx.doi.org/10.1016/j.accfor.2017.04.003

Nnadi, M., \& Soobaroyen, T. (2015). International financial reporting standards and foreign direct investment: The case of Africa. Advances in Accounting, 31(2), 228-238. https://doi.org/10.1016/J.ADIAC.2015.09.007

Nobes, C. (2003). On the myth of "Anglo-Saxon" financial accounting: A comment. International Journal of Accounting, 38(1), 95-104. https://doi.org/10.1016/S0020-7063(02)00213-3

Okike, E. (2004). Management of crisis: The response of the auditing profession in Nigeria to the challenge to its legitimacy. Accounting, Auditing \& Accountability Journal, 17(5), 705-730. https://doi.org/10.1108/09513570410567782

Palea, V. (2018). Financial reporting for sustainable development: Critical insights into IFRS implementation in the European Union. Accounting Forum, 42, 248-260. https://doi.org/10.1016/j.accfor.2018.08.001

Pawsey, N. L. (2017). IFRS adoption: A costly change that keeps on costing. Accounting Forum, 41(2), 116-131. https://doi.org/10.1016/J.ACCFOR.2017.02.002

Samaha, K., \& Khlif, H. (2016). Adoption of and compliance with IFRS in developing countries. Journal of Accounting in Emerging Economies, 6(1), 33-49. https://doi.org/10.1108/JAEE-02-2013-0011

Sato, S., \& Takeda, F. (2017). IFRS Adoption and Stock Prices of Japanese Firms in Governance System Transition. International Journal of Accounting, 52(November), 319-337.

Tunyi, A. A., Agyei-Boapeah, H., Areneke, G., \& Agyemang, J. (2019). Internal capabilities, national governance and performance in African firms. Research in International Business and Finance, 50, 18-37. https://doi.org/10.1016/j.ribaf.2019.04.009

Tunyi, A. A., \& Ntim, C. G. (2016). Location Advantages, Governance Quality, Stock Market Development and Firm Characteristics as Antecedents of African M\&As. Journal of International Management, 22(2), 147-167. https://doi.org/10.1016/j.intman.2016.01.005

Uddin, S., \& Tsamenyi, M. (2005). Public sector reforms and the public interest: A case study of accounting control changes and performance monitoring in a Ghanaian state-owned enterprise. Accounting, Auditing and Accountability Journal, 18(5), 648-674. https://doi.org/10.1108/09513570510620493 
Figures

Figure 1: Rule of Law Index

by Continent

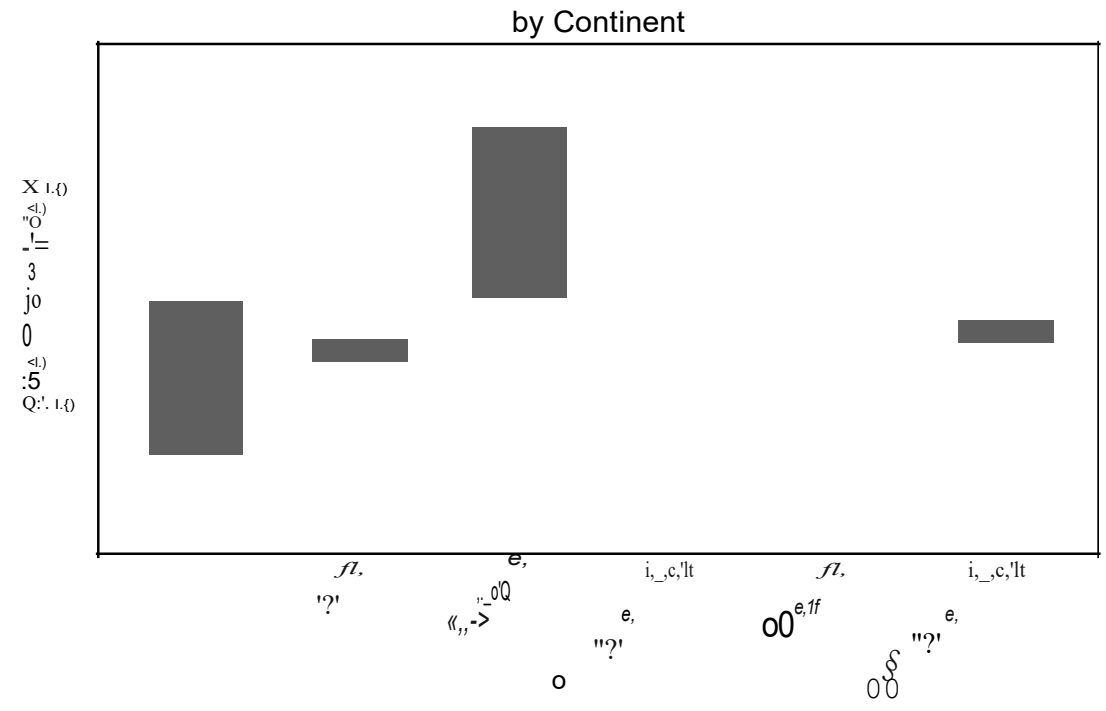

Figure 2: Rule of Law Index

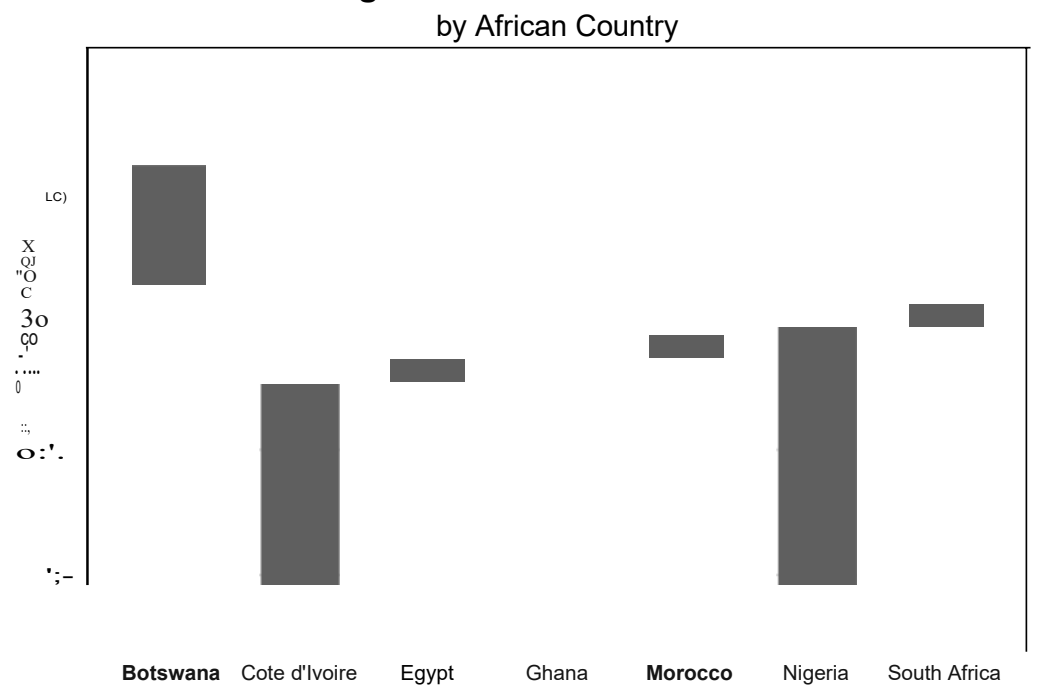


Tables

Table 1: Sample construction process and salient features across sample countries

\begin{tabular}{lr}
\hline Panel A: Sample construction process & 29,288 \\
\hline Full initial sample & 9,018 \\
Less: Firms in the financial and utility sectors & 10,202 \\
Less: Missing observations & 4,140 \\
Less: Firms with more than 100\% growth in assets & 5,928 \\
Less: Restricted event window period [-5yr, +5yr] & 4,749 \\
\hline Final sample & \\
\hline
\end{tabular}

Panel B: IFRS adoption and institutional features in sample countries

\begin{tabular}{llllrr}
\hline Country & Adoption year & Adoption type & Accounting tradition & Rule of Law index & Obs. \\
\hline Botswana & 2007 & Full & Anglo-Saxon & 0.640 & 15 \\
Ivory Coast & 2012 & Full & Franco-German & -1.195 & 42 \\
Egypt & 2006 & Modified & Anglo-Saxon & -2.232 & 391 \\
Ghana & 2007 & Full & Anglo-Saxon & 0.030 & 63 \\
Morocco & 2004 & Partial & Franco-German & -0.134 & 34 \\
Nigeria & 2012 & Full & Anglo-Saxon & -1.171 & 177 \\
South Africa & 2005 & Full & Anglo-Saxon & 0.142 & 4,027 \\
Full sample & & & & -0.274 & 4,749 \\
\hline
\end{tabular}

Full adoption applies when a country wholly adopts IFRS while partial/modified adoptions refers to cases where a country either selects aspects of IFRS that it wishes to adopt or makes changes to the IFRS to reflect local conditions. Accounting tradition refers to the orientation underpinning local accounting practice and the design of local accounting standards, as classified by Elad (2015). Rule of Law index is based on World Governance Indicators data (see Kaufmann et al., 2010). 


\begin{tabular}{|c|c|c|c|c|c|c|c|c|c|}
\hline \multicolumn{10}{|c|}{ Table 2: Descriptive statistics and correlation } \\
\hline \multirow{3}{*}{ Variables } & tatistic & & & & & \multirow[b]{3}{*}{ SD } & \multirow{2}{*}{\multicolumn{2}{|c|}{ Post-IFRS [+1yr, +5yr] }} & \multirow[b]{3}{*}{ SD } \\
\hline & \multicolumn{3}{|c|}{ Event window $[-5 y r,+5 y r]$} & \multicolumn{2}{|c|}{ Pre-IFRS [-5yr, -1yr] } & & & & \\
\hline & Obs. & Mean & SD & Obs. & Mean & & Obs. & Mean & \\
\hline Tobin's q & 4747 & 1.613 & 0.836 & 2123 & 1.409 & 0.727 & 2092 & $1.787^{* * *}$ & 0.894 \\
\hline Cash flow & 4533 & 0.139 & 0.125 & 1942 & 0.130 & 0.124 & 2092 & $0.146^{* * *}$ & 0.125 \\
\hline Sales growth & 4533 & 0.182 & 0.532 & 1942 & 0.218 & 0.640 & 2092 & $0.164 * * *$ & 0.399 \\
\hline Size & 4533 & 10.577 & 1.958 & 1942 & 10.557 & 1.855 & 2092 & 10.636 & 2.025 \\
\hline Leverage & 4533 & 0.164 & 0.139 & 1942 & 0.162 & 0.135 & 2092 & 0.165 & 0.143 \\
\hline Capex & 4533 & 0.087 & 0.074 & 1942 & 0.086 & 0.079 & 2092 & 0.088 & 0.070 \\
\hline PPE & 4533 & 0.371 & 0.223 & 1942 & 0.378 & 0.228 & 2092 & $0.363 * *$ & 0.216 \\
\hline Industry Median Q & 4533 & 1.416 & 0.448 & 1942 & 1.200 & 0.370 & 2092 & $1.625 * * *$ & 0.449 \\
\hline \multicolumn{10}{|c|}{ Panel B: Correlation matrix } \\
\hline Variables & No. & 1 & 2 & 3 & 4 & 5 & 6 & 7 & 8 \\
\hline Tobin's q & 1 & 1.000 & & & & & & & \\
\hline Cash flow & 2 & $0.409 * * *$ & 1.000 & & & & & & \\
\hline Sales growth & 3 & $0.030^{*}$ & $0.241 * * *$ & 1.000 & & & & & \\
\hline Size & 4 & $0.203 * * *$ & $0.130 * * *$ & -0.004 & 1.000 & & & & \\
\hline Leverage & 5 & $-0.134 * * *$ & $-0.283 * * *$ & 0.001 & $0.081 * * *$ & 1.000 & & & \\
\hline Capex & 6 & $0.128 * * *$ & $0.298 * * *$ & $0.256 * * *$ & $0.142 * * *$ & $0.131 * * *$ & 1.000 & & \\
\hline PPE & 7 & $0.099 * * *$ & $0.106 * * *$ & 0.016 & $0.271 * * *$ & $0.210 * * *$ & $0.424 * * *$ & 1.000 & \\
\hline Industry Median Q & 8 & $0.355 * * *$ & $0.144 * * *$ & $0.029 *$ & $0.154 * * *$ & $-0.069 * * *$ & $0.063 * * *$ & -0.001 & 1.000 \\
\hline
\end{tabular}

All variables are defined in Appendix A. ***,**, and * represent statistical significance at the $1 \%, 5 \%$, and $10 \%$ levels, respectively. 


\begin{tabular}{|c|c|c|c|c|c|c|c|}
\hline Sample & {$[-5 y r,+5 y r]$} & {$[-5 y r,+5 y r]$} & {$[-4 y r,+4 y r]$} & {$[-3 y r,+3 y r]$} & {$[-2 \mathrm{yr},+2 \mathrm{yr}]$} & {$[-1 \mathrm{yr},+1 \mathrm{yr}]$} & {$[-5 \mathrm{yr},+5 \mathrm{yr}]$} \\
\hline Model & (1) & (2) & (3) & (4) & (5) & (6) & (7) \\
\hline \multirow[t]{2}{*}{ Post-IFRS } & $0.375^{* * *}$ & $0.358 * * *$ & $0.385 * * *$ & $0.482 * * *$ & $0.465 * * *$ & $0.416^{* * *}$ & $0.321 * * *$ \\
\hline & $(0.034)$ & $(0.044)$ & $(0.047)$ & $(0.056)$ & (0.063) & $(0.084)$ & $(0.046)$ \\
\hline \multirow[t]{2}{*}{ Cash flow } & & $1.138 * * *$ & $1.137 * * *$ & $1.093 * * *$ & $0.848^{* * *}$ & 0.195 & $1.030 * * *$ \\
\hline & & $(0.153)$ & $(0.157)$ & $(0.170)$ & $(0.212)$ & (0.396) & $(0.144)$ \\
\hline \multirow[t]{2}{*}{ Sales growth } & & -0.015 & 0.000 & 0.020 & 0.091 & 0.161 & -0.006 \\
\hline & & $(0.025)$ & $(0.028)$ & $(0.037)$ & (0.064) & $(0.105)$ & $(0.029)$ \\
\hline \multirow[t]{2}{*}{ Size } & & $-0.287 * * *$ & $-0.323 * * *$ & $-0.277 * * *$ & -0.150 & -0.055 & $-0.291 * * *$ \\
\hline & & $(0.045)$ & $(0.055)$ & $(0.077)$ & $(0.102)$ & $(0.176)$ & $(0.047)$ \\
\hline \multirow[t]{2}{*}{ Leverage } & & 0.129 & 0.170 & 0.165 & 0.394 & -0.550 & 0.170 \\
\hline & & $(0.165)$ & (0.199) & $(0.285)$ & $(0.291)$ & $(0.646)$ & $(0.159)$ \\
\hline \multirow[t]{2}{*}{ Capex } & & -0.347 & $-0.524 *$ & $-0.607 *$ & -0.743 & -1.635 & -0.278 \\
\hline & & $(0.228)$ & $(0.285)$ & $(0.335)$ & $(0.475)$ & $(1.010)$ & $(0.234)$ \\
\hline \multirow[t]{2}{*}{ PPE } & & $-0.735 * * *$ & $-0.537 * *$ & -0.370 & $-1.196^{* * *}$ & -0.748 & $-0.586^{* * *}$ \\
\hline & & $(0.199)$ & $(0.231)$ & $(0.270)$ & $(0.288)$ & $(0.656)$ & $(0.192)$ \\
\hline \multirow[t]{2}{*}{ Industry Median Q } & & $0.273 * * *$ & $0.242 * * *$ & $0.106^{* *}$ & $0.285^{* * *}$ & 0.209 & $0.272 * * *$ \\
\hline & & $(0.037)$ & $(0.038)$ & $(0.050)$ & $(0.091)$ & $(0.158)$ & $(0.038)$ \\
\hline \multirow[t]{2}{*}{ Rule of law } & & & & & & & $37.961 * * *$ \\
\hline & & & & & & & $(13.416)$ \\
\hline \multirow[t]{2}{*}{ Post-IFRS x Rule of law } & & & & & & & $30.946 * * *$ \\
\hline & & & & & & & $(9.024)$ \\
\hline \multirow[t]{2}{*}{ Constant } & $1.410^{* * *}$ & $4.199 * * *$ & $4.546 * * *$ & $4.195 * * *$ & $2.952 * * *$ & 2.264 & $4.177 * * *$ \\
\hline & $(0.017)$ & $(0.487)$ & $(0.588)$ & $(0.805)$ & $(1.061)$ & $(1.832)$ & $(0.510)$ \\
\hline Obs. & 4,215 & 4,034 & 3,354 & 2,614 & 1,807 & 943 & 3,696 \\
\hline Adj. $R^{2}$ & 0.59 & 0.65 & 0.65 & 0.65 & 0.71 & 0.72 & 0.65 \\
\hline F-stats. & 124.60 & 33.21 & 31.43 & 32.49 & 35.63 & 16.58 & 28.06 \\
\hline
\end{tabular}

All variables are defined in Appendix A. ${ }^{* *},{ }^{* *}$, and $*$ represent statistical significance at the $1 \%, 5 \%$, and $10 \%$ levels, respectively. Standard errors are reported in parantheses. 


\begin{tabular}{|c|c|c|c|c|c|c|}
\hline \multicolumn{7}{|c|}{ Table 4: The value of IFRS adoption and the risk of financial constraint } \\
\hline \multirow{3}{*}{$\begin{array}{l}\text { Constraint proxy } \\
\text { Sub-samples } \\
\text { Models }\end{array}$} & \multicolumn{2}{|l|}{ Age } & \multicolumn{2}{|l|}{ Size } & \multicolumn{2}{|c|}{ Asset liquidity } \\
\hline & Young & Mature & Small & Large & Low & High \\
\hline & (1) & (2) & (3) & (4) & (5) & (6) \\
\hline \multirow[t]{2}{*}{ Post-IFRS } & $0.442 * * *$ & $0.308 * * *$ & $0.312 * * *$ & $0.259 * * *$ & $0.615^{* * *}$ & $0.232 * * *$ \\
\hline & (0.086) & (0.048) & $(0.072)$ & $(0.049)$ & (0.091) & (0.047) \\
\hline \multirow[t]{2}{*}{ Cash flow } & $0.752 * * *$ & $1.228 * * *$ & $0.882 * * *$ & $1.045^{* * *}$ & $1.447 * * *$ & $0.501 * * *$ \\
\hline & $(0.182)$ & $(0.255)$ & $(0.215)$ & $(0.222)$ & (0.304) & (0.171) \\
\hline \multirow[t]{2}{*}{ Sales growth } & 0.005 & -0.025 & -0.052 & 0.014 & -0.057 & $-0.053 * *$ \\
\hline & $(0.031)$ & $(0.081)$ & $(0.041)$ & $(0.051)$ & $(0.046)$ & $(0.027)$ \\
\hline \multirow[t]{2}{*}{ Size } & $-0.322 * * *$ & $-0.275^{* * *}$ & $-0.185^{* *}$ & $-0.343^{* * *}$ & $-0.530 * * *$ & -0.081 \\
\hline & $(0.070)$ & $(0.081)$ & $(0.076)$ & $(0.086)$ & $(0.105)$ & $(0.056)$ \\
\hline \multirow[t]{2}{*}{ Leverage } & 0.087 & $-0.760 * * *$ & 0.022 & $-0.683^{* * *}$ & -0.481 & $-0.339 *$ \\
\hline & $(0.206)$ & $(0.281)$ & $(0.275)$ & $(0.255)$ & $(0.433)$ & $(0.199)$ \\
\hline \multirow[t]{2}{*}{ Capex } & $-0.527^{*}$ & $-1.265^{* * *}$ & 0.460 & $-1.805^{* * *}$ & $-1.292 * * *$ & 0.464 \\
\hline & $(0.313)$ & $(0.470)$ & (0.333) & $(0.382)$ & (0.494) & $(0.295)$ \\
\hline \multirow[t]{2}{*}{ PPE } & -0.429 & $-1.406 * * *$ & $-0.534^{*}$ & $-0.730 * *$ & -0.371 & $-1.346^{* * *}$ \\
\hline & $(0.314)$ & (0.293) & $(0.297)$ & $(0.281)$ & $(0.453)$ & $(0.307)$ \\
\hline \multirow[t]{2}{*}{ Industry Median Q } & $0.304 * * *$ & $0.293 * * *$ & $0.326^{* * *}$ & $0.206^{* * *}$ & $0.226^{* * *}$ & $0.261 * * *$ \\
\hline & $(0.051)$ & (0.068) & (0.074) & (0.072) & (0.069) & (0.062) \\
\hline \multirow[t]{2}{*}{ Constant } & $4.031 * * *$ & $5.138 * * *$ & $2.360 * * *$ & $6.149^{* * *}$ & $7.318 * * *$ & $1.984 * * *$ \\
\hline & $(0.672)$ & (0.966) & $(0.622)$ & (1.168) & (1.164) & $(0.556)$ \\
\hline Obs. & 1,838 & 1,296 & 1,355 & 1,320 & 1,521 & 1,480 \\
\hline $\operatorname{Adj} . R^{2}$ & 0.61 & 0.74 & 0.61 & 0.74 & 0.62 & 0.67 \\
\hline F-stats. & 13.20 & 43.73 & 11.55 & 25.20 & 19.25 & 14.00 \\
\hline
\end{tabular}

All variables are defined in Appendix A. ***, **, and * represent statistical significance at the 1\%, 5\%, and 10\% levels, respectively. Standard errors are reported in parantheses. 


\begin{tabular}{|c|c|c|c|c|}
\hline \multicolumn{5}{|c|}{ Table 5: Alternative measures of value } \\
\hline Dependent variable & $\mathbf{M V} / \mathbf{E}$ & ROA & ROE & Bid-Ask Spread \\
\hline Variables & (1) & (2) & (3) & (4) \\
\hline \multirow[t]{2}{*}{ Post-IFRS } & $0.754 * * *$ & $0.015^{* * *}$ & $0.045 * * *$ & $-0.579 * *$ \\
\hline & $(0.125)$ & $(0.005)$ & $(0.013)$ & $(0.257)$ \\
\hline \multirow[t]{2}{*}{ Cash flow } & $2.832 * * *$ & $0.215^{* * *}$ & $0.498 * * *$ & -0.315 \\
\hline & $(0.464)$ & $(0.021)$ & $(0.053)$ & $(0.694)$ \\
\hline \multirow[t]{2}{*}{ Sales growth } & $-0.125 * *$ & 0.005 & 0.007 & 0.055 \\
\hline & $(0.057)$ & $(0.003)$ & $(0.008)$ & $(0.253)$ \\
\hline \multirow[t]{2}{*}{ Size } & $-0.631 * * *$ & $-0.032 * * *$ & $-0.075 * * *$ & -0.339 \\
\hline & $(0.120)$ & $(0.006)$ & $(0.015)$ & $(0.340)$ \\
\hline \multirow[t]{2}{*}{ Leverage } & $2.307 * * *$ & 0.013 & $0.325^{* * *}$ & -1.458 \\
\hline & $(0.623)$ & $(0.022)$ & $(0.078)$ & $(1.210)$ \\
\hline \multirow[t]{2}{*}{ Capex } & -0.295 & 0.005 & 0.047 & $4.051^{*}$ \\
\hline & $(0.563)$ & $(0.031)$ & $(0.073)$ & $(2.273)$ \\
\hline \multirow[t]{2}{*}{ PPE } & -0.424 & -0.044 & -0.095 & -0.972 \\
\hline & $(0.426)$ & $(0.028)$ & $(0.068)$ & (1.549) \\
\hline \multirow[t]{2}{*}{ Industry Median Q } & & & & 0.211 \\
\hline & & & & $(0.319)$ \\
\hline \multirow[t]{2}{*}{ Industry Median MV/E } & $0.390 * * *$ & & & \\
\hline & $(0.048)$ & & & \\
\hline \multirow[t]{2}{*}{ Industry Median ROA } & & $0.211^{* * *}$ & & \\
\hline & & $(0.061)$ & & \\
\hline \multirow[t]{2}{*}{ Industry Median ROE } & & & $0.162 *$ & \\
\hline & & & $(0.089)$ & \\
\hline \multirow[t]{2}{*}{ Constant } & $7.491 * * *$ & $0.404 * * *$ & $0.884 * * *$ & 4.540 \\
\hline & $(1.232)$ & $(0.064)$ & $(0.162)$ & (4.077) \\
\hline $\mathbf{N}$ & 3,704 & 3,704 & 3,704 & 216 \\
\hline Adj. $R^{2}$ & 0.64 & 0.57 & 0.45 & 0.43 \\
\hline F-stat. & 28.10 & 22.39 & 16.45 & 3.78 \\
\hline
\end{tabular}

All variables are defined in Appendix A. ***, **, and * represent statistical significance at the $1 \%, 5 \%$, and $10 \%$ levels, respectively. Standard errors are reported in parantheses. 


\begin{tabular}{|c|c|c|c|c|c|}
\hline \multicolumn{6}{|c|}{ Table 6: Further interaction analysis conditional on firms' financial constraint and external relations } \\
\hline \multirow[b]{2}{*}{ Variables } & \multicolumn{3}{|c|}{ Financial constraint proxies } & \multicolumn{2}{|c|}{ External relations proxies } \\
\hline & Age & Size & Asset liquidity & $\begin{array}{l}\text { Foreign } \\
\text { shareholders }\end{array}$ & $\begin{array}{l}\text { Foreign } \\
\text { sales }\end{array}$ \\
\hline Models & (1) & $(2)$ & (3) & (4) & (5) \\
\hline \multirow[t]{2}{*}{ Post-IFRS } & $0.257 * * *$ & $0.253 * * *$ & $0.252 * * *$ & $0.201 * * *$ & $0.273 * * *$ \\
\hline & $(0.045)$ & $(0.037)$ & $(0.042)$ & $(0.059)$ & $(0.052)$ \\
\hline \multirow[t]{2}{*}{ Financial constraint } & -0.042 & -0.032 & $-0.051 *$ & & \\
\hline & (0.039) & (0.039) & $(0.027)$ & & \\
\hline \multirow[t]{2}{*}{ Foreign shareholders } & & & & -0.056 & \\
\hline & & & & $(0.040)$ & \\
\hline \multirow[t]{2}{*}{ Foreign sales } & & & & & $-0.075 * *$ \\
\hline & & & & & $(0.037)$ \\
\hline \multirow[t]{2}{*}{ Financial constraint*Post-IFRS } & $0.206 * * *$ & $0.169 * *$ & $0.167 * * *$ & & \\
\hline & $(0.075)$ & $(0.073)$ & $(0.046)$ & & \\
\hline \multirow[t]{2}{*}{ External relations*Post-IFRS } & & & & $0.160 * * *$ & $0.121 * *$ \\
\hline & & & & $(0.059)$ & $(0.056)$ \\
\hline \multirow[t]{2}{*}{ Cash flow } & $1.220 * * *$ & $1.262 * * *$ & $1.266^{* * *}$ & $1.256^{* * *}$ & $1.246^{* * *}$ \\
\hline & $(0.156)$ & $(0.159)$ & $(0.159)$ & $(0.159)$ & $(0.158)$ \\
\hline \multirow[t]{2}{*}{ Sales growth } & -0.006 & -0.008 & -0.006 & -0.007 & -0.006 \\
\hline & $(0.025)$ & $(0.025)$ & $(0.025)$ & $(0.025)$ & $(0.025)$ \\
\hline \multirow[t]{2}{*}{ Size } & $-0.335^{* * *}$ & $-0.288 * * *$ & $-0.299 * * *$ & $-0.298 * * *$ & $-0.300 * * *$ \\
\hline & $(0.049)$ & $(0.045)$ & $(0.045)$ & $(0.045)$ & $(0.044)$ \\
\hline \multirow[t]{2}{*}{ Leverage } & 0.189 & 0.103 & 0.134 & 0.136 & 0.166 \\
\hline & $(0.166)$ & $(0.162)$ & $(0.161)$ & $(0.165)$ & $(0.162)$ \\
\hline \multirow[t]{2}{*}{ Capex } & $-0.452 *$ & $-0.476^{* *}$ & $-0.445^{*}$ & $-0.420 *$ & $-0.435^{*}$ \\
\hline & $(0.231)$ & $(0.232)$ & $(0.227)$ & $(0.231)$ & $(0.232)$ \\
\hline \multirow[t]{2}{*}{ PPE } & $-0.778 * * *$ & $-0.714 * * *$ & $-0.667 * * *$ & $-0.696 * * *$ & $-0.736 * * *$ \\
\hline & $(0.194)$ & $(0.195)$ & $(0.193)$ & $(0.196)$ & $(0.199)$ \\
\hline \multirow[t]{2}{*}{ Industry Median Q } & $0.283 * * *$ & $0.288 * * *$ & $0.283 * * *$ & $0.282 * * *$ & $0.288 * * *$ \\
\hline & $(0.042)$ & $(0.041)$ & $(0.041)$ & $(0.042)$ & $(0.042)$ \\
\hline \multirow[t]{2}{*}{ Constant } & $4.716 * * *$ & $4.207 * * *$ & $4.309 * * *$ & $4.332 * * *$ & $4.351 * * *$ \\
\hline & $(0.537)$ & $(0.503)$ & $(0.501)$ & $(0.503)$ & $(0.478)$ \\
\hline $\mathbf{N}$ & 3,894 & 3,894 & 3,894 & 3,894 & 3,894 \\
\hline Adj. $\mathbf{R}^{2}$ & 0.66 & 0.65 & 0.65 & 0.65 & 0.65 \\
\hline F-stat. & 24.88 & 34.86 & 28.57 & 25.51 & 30.61 \\
\hline
\end{tabular}

All variables are defined in Appendix A. ***,**, and * represent statistical significance at the 1\%, 5\%, and 10\% levels, respectively. Standard errors are reported in parantheses. 
Table 7: Further analysis relating to similarities and differences across sample countries

\begin{tabular}{|c|c|c|c|c|c|c|c|c|c|c|}
\hline \multirow[b]{3}{*}{ Variables } & \multicolumn{2}{|c|}{ Implementation of IFRS } & \multicolumn{2}{|c|}{ Accounting tradition } & \multicolumn{2}{|c|}{ Legal environment } & \multicolumn{4}{|c|}{ Country analyses } \\
\hline & Full & Partial/Modified & Franco-German & Anglo-Saxon & Strong & Weak & Nigeria & Egypt & South Africa & Others \\
\hline & (1) & (2) & (3) & (4) & (5) & (6) & (7) & (8) & (9) & (10) \\
\hline \multirow[t]{2}{*}{ Post-IFRS } & $0.358 * * *$ & 0.159 & 0.301 & $0.342 * * *$ & $0.378 * * *$ & 0.076 & -0.060 & 0.102 & $0.380 * * *$ & $0.388^{*}$ \\
\hline & $(0.045)$ & $(0.201)$ & $(0.204)$ & $(0.044)$ & $(0.047)$ & $(0.135)$ & $(0.202)$ & $(0.259)$ & $(0.048)$ & $(0.197)$ \\
\hline \multirow[t]{2}{*}{ Cash flow } & $1.235^{* * *}$ & $0.867 *$ & 0.742 & $1.208 * * *$ & $1.273^{* * *}$ & $0.977^{* *}$ & 0.981 & $1.007 *$ & $1.322 * * *$ & 0.248 \\
\hline & $(0.164)$ & $(0.457)$ & $(0.440)$ & $(0.156)$ & $(0.167)$ & $(0.390)$ & $(0.671)$ & $(0.536)$ & $(0.172)$ & $(0.358)$ \\
\hline \multirow[t]{2}{*}{ Sales growth } & -0.027 & 0.089 & -0.193 & -0.008 & -0.038 & 0.083 & $0.120 * *$ & 0.118 & -0.038 & -0.103 \\
\hline & $(0.024)$ & $(0.113)$ & $(0.115)$ & $(0.025)$ & $(0.023)$ & $(0.074)$ & $(0.059)$ & $(0.135)$ & $(0.024)$ & $(0.066)$ \\
\hline \multirow[t]{2}{*}{ Size } & $-0.301 * * *$ & -0.068 & 0.333 & $-0.287 * * *$ & $-0.305 * * *$ & -0.220 & $-0.629 *$ & -0.135 & $-0.303 * * *$ & -0.531 \\
\hline & $(0.045)$ & $(0.254)$ & $(0.380)$ & $(0.044)$ & $(0.046)$ & $(0.223)$ & $(0.324)$ & $(0.270)$ & $(0.046)$ & $(0.538)$ \\
\hline \multirow{2}{*}{ Leverage } & 0.114 & 0.600 & -2.005 & 0.163 & 0.111 & 0.485 & 0.570 & 0.675 & 0.126 & -0.159 \\
\hline & $(0.166)$ & $(0.645)$ & (1.768) & $(0.162)$ & $(0.170)$ & $(0.480)$ & $(0.660)$ & $(0.668)$ & $(0.173)$ & $(0.544)$ \\
\hline \multirow{2}{*}{ Capex } & -0.343 & -0.960 & 1.288 & $-0.397^{*}$ & -0.329 & -0.788 & $-0.997 * *$ & -1.015 & -0.354 & 0.487 \\
\hline & $(0.235)$ & $(0.962)$ & (2.097) & $(0.232)$ & $(0.252)$ & $(0.527)$ & $(0.469)$ & (1.088) & $(0.257)$ & $(0.888)$ \\
\hline \multirow[t]{2}{*}{ PPE } & $-0.670 * * *$ & -0.878 & -0.045 & $-0.681 * * *$ & $-0.679 * * *$ & -0.329 & 0.603 & -0.877 & $-0.634 * * *$ & $-1.850^{* *}$ \\
\hline & $(0.198)$ & $(0.732)$ & (1.809) & $(0.194)$ & $(0.204)$ & $(0.529)$ & $(0.790)$ & $(0.774)$ & $(0.205)$ & $(0.886)$ \\
\hline \multirow[t]{2}{*}{ Industry Median Q } & $0.291 * * *$ & $0.345 * *$ & -0.200 & $0.305^{* * *}$ & $0.275^{* * *}$ & $0.233 * * *$ & $0.125^{*}$ & $0.407 * *$ & $0.274 * * *$ & 0.098 \\
\hline & $(0.042)$ & $(0.152)$ & $(0.112)$ & $(0.040)$ & (0.038) & $(0.071)$ & $(0.065)$ & $(0.160)$ & $(0.040)$ & $(0.140)$ \\
\hline \multirow{2}{*}{ Constant } & $4.304 * * *$ & 1.884 & -1.897 & $4.113^{* * *}$ & $4.316^{* * *}$ & 3.704 & $9.366^{* *}$ & 2.372 & $4.289^{* * *}$ & 7.251 \\
\hline & $(0.490)$ & $(2.546)$ & $(5.011)$ & $(0.480)$ & $(0.501)$ & (2.403) & (4.033) & $(2.550)$ & $(0.503)$ & $(5.179)$ \\
\hline $\mathbf{N}$ & 3,704 & 343 & 62 & 3,985 & 3,543 & 504 & 161 & 281 & 3,488 & 117 \\
\hline Adj. $R^{2}$ & 0.65 & 0.65 & 0.89 & 0.64 & 0.62 & 0.74 & 0.80 & 0.54 & 0.62 & 0.80 \\
\hline F-stat. & 33.53 & 3.74 & 5.54 & 34.71 & 36.73 & 3.28 & 2.80 & 3.37 & 36.79 & 2.18 \\
\hline
\end{tabular}




\begin{tabular}{|c|c|}
\hline \multicolumn{2}{|r|}{ Appendix A - Variable definitions } \\
\hline Variable & Definitions \\
\hline Tobin's q (Q) & Market value of equity plus total debt divided by total assets. \\
\hline Market to book ratio (MV/E) & The ratio of market value of equity to book equity. \\
\hline Return on asset (ROA) & The ratio of net profit to total asset. \\
\hline Return on asset (ROE) & The ratio of net profit to book equity. \\
\hline Bid-ask spread & The average difference between the selling and buying stock prices in local currency. \\
\hline Post-IFRS & An indicator variable that takes the value of 1 from the first year of IFRS adoption, and zero otherwise \\
\hline Cash flow & Net cash flow from operations divided by total assets. \\
\hline Sales growth & The annual sales growth. \\
\hline Size & The $\log$ of total assets. \\
\hline Leverage & The ratio of total debt to total assets. \\
\hline Capital expenditure (Capex) & Capital expenditure divided by total assets. \\
\hline Plant, property and equipment (PPE) & Plant, property and equipment divided by total assets. \\
\hline Age & The current year minus the first year that the firm appears in the database. \\
\hline Asset liquidity & $\frac{\text { Cash }}{\text { Marlet valuet }-1^{-1}}+0.75 x \frac{\text { Current assets-Cash }}{\text { Market valuet }-1}+0.5 x \frac{P P E}{\text { Market valuet }-1}$ (see Ortiz-Molina and Phillips, 2014). \\
\hline Industry median $\mathrm{Q}$ & The industrial median Tobin's q in a year. \\
\hline Industry median MV/E & The industrial median MV/E in a year. \\
\hline Industry median ROA & The industrial median ROA in a year. \\
\hline Industry median ROE & The industrial median ROE in a year. \\
\hline Rule of law & Rule of law estimate from the World Bank (World Development Indicators). \\
\hline
\end{tabular}

